\title{
Investigations on the biotransformation capacity of organophosphates in the mollusc Dreissena polymorpha $\mathrm{P}$.
}

\author{
Carole Dauberschmidt*, Daniel R. Dietrich ${ }^{1}$, Christian Schlatter \\ Institute of Toxicology, Federal Institute of Technology and University of Zürich, Schorenstr. 16, \\ CH-8603 Schwerzenbach, Switzerland
}

\begin{abstract}
Microsomes of Dreissena polymorpha were able to biotransform the organophosphates thiometon and disulfoton significantly after $1 \mathrm{~h}$ incubation at $10^{\circ} \mathrm{C}$. Contrarily to vertebrates, biotransformation with mussel microsomes occurred without the addition of reduction equivalents (NADPH), at a considerably lower extent however. Metabolites of thiometon and disulfoton were detected with gas chromatography/mass spectrometry (GC/MS) analysis. The P450 content of whole mussel tissue was $8 \mathrm{pmol} \mathrm{mg}^{-1}$ protein being two orders of magnitude lower than the amounts measured in mammal liver. Ethoxycoumarin deethylase (ECOD) activity could be measured at $10^{\circ} \mathrm{C}$ in microsomes of Dreissena $\left(22 \mathrm{pmol} \mathrm{min}^{-1}\right.$ $\mathrm{mg}^{-1}$ protein) but not at $37^{\circ} \mathrm{C}$. ECOD activity was inhibited in the presence of NADPH (measured activity $3 \mathrm{pmol} \mathrm{min}^{-1} \mathrm{mg}^{-1}$ ).
\end{abstract}

Keywords: Dreissena polymorpha; Mixed-function oxygenase (MFO); Cytochrome P450; ECOD activity; Organophosphate metabolism

\section{Introduction}

Organophosphates were shown to be toxic to the freshwater mollusc Dreissena polymorpha only at concentrations higher than $2 \mathrm{mg} \mathrm{l}^{-1}(96 \mathrm{~h})$. In the mussel tissue, concentrations ten times above those present in the ambient water were found (Dauberschmidt et al., 1996).

In vertebrates, organophosphate compounds are readily metabolised in the liver (Hill, 1988). The first and most important stage in metabolism of many organic compounds as well as organophosphates is mediated by the mixed-function mono-

\footnotetext{
*Corresponding author at: SOGEDEC, 14, rue Auguste Lumière, L-1950 Luxembourg, Luxembourg.

${ }^{1}$ Present address: Ecotoxicology, University of Konstanz, D-78434 Konstanz, Germany.
} 
oxygenase (MFO) system. Organodithiophosphates are oxidised by cytochrome P450-containing MFO in the liver to the more potent oxygen analogues (Fig. 1). These active pesticides are then hydrolysed by esterases and rendered inactive (Fest and Schmidt, 1970; Singh and Agarwal, 1983; Riviere, 1992; De Bruijn et al., 1993). Similar mechanisms involved in organophosphate metabolism as observed in vertebrates are assumed to take place in molluscs. The digestive glands of snails are considered to be able to convert organophosphates to their active oxygen analogue with the help of MFO (Mahendru and Agarwal, 1983; Takimoto et al., 1987).

The relatively high organophosphate tissue concentrations found in Dreissena, however, cannot be reconciled with a high rate of metabolism as found in vertebrates. Xenobiotics in general have been shown to be metabolised very slowly or not at all in bivalve molluscs (Payne et al., 1987). Low metabolism rates are seen as the cause for the high bioaccumulation of xenobiotics in the tissue of these aquatic invertebrates (Livingstone et al., 1989) and as a consequence of lacking bioactivation may also explain the high tolerance to elevated pollutant concentrations (Solé et al., 1994).

MFO systems have so far been shown to be present in 18 species of marine invertebrates belonging to four phylas, one of them being molluscs (Lee, 1981), Cytochrome P450-containing MFOs were shown to be localised primarily in microsomes of the digestive gland (Livingstone et al., 1989). The known functions of this gland are digestion, storage and distribution of food. It may be a primary site for xenobiotic uptake into mussels, probably also due to its high lipid level (Suteau et al., 1987). Freshwater invertebrates have so far not been examined for MFO activity. In the marine species studied, the components and cofactors required are thought to be similar to the ones found in insect and vertebrate MFO systems, but the MFO activity and the content of cytochrome P450 are generally lower than in vertebrates. The function and role of these enzymes, however, in xenobiotic as well as in endogenous metabolism of molluscs are still essentially unknown (Livingstone, 1990).

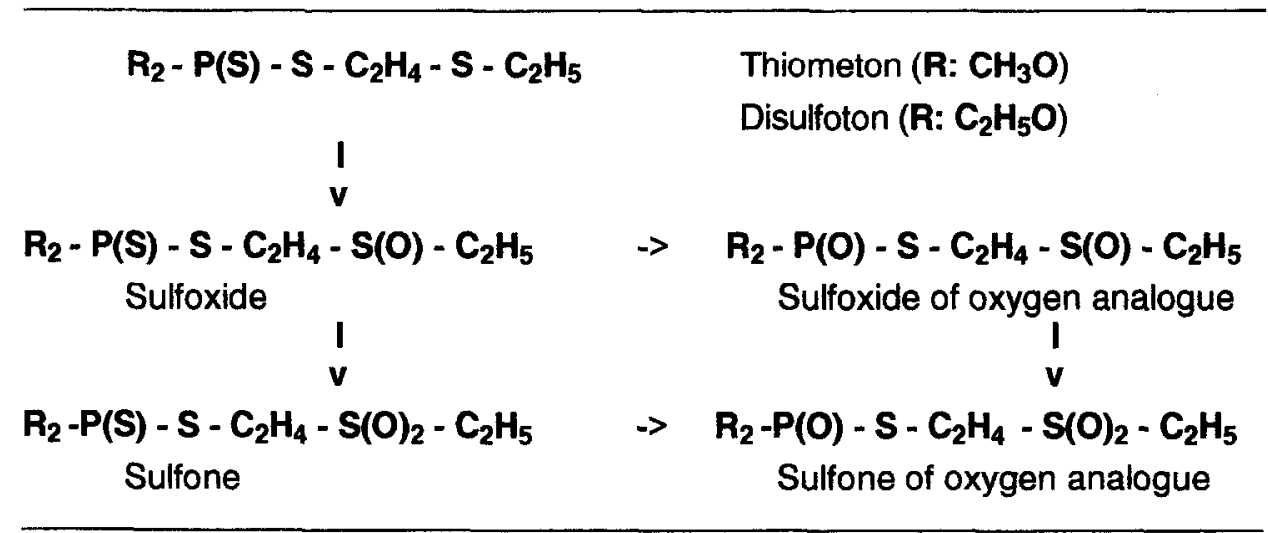

Fig. 1. Metabolic pathway of dithio-organophosphates. 
Bivalve molluscs, due to their immobile benthic 'lifestyle', would have obvious advantages as monitoring organisms (Payne, 1984). Far more research is nevertheless required on the characterisation of detoxification enzymes of these invertebrates and their responsiveness to pollutants before valid interpretations of such data in terms of environmental risk assessment can be made (Lagadic et al., 1994).

The aim of this study was to characterise the metabolic capacity of Dreissena using in vitro techniques and chemical analysis. Organophosphates and ethoxycoumarin (ECOD assay) were used as substrates, and rat liver microsomal preparations were used for comparison.

\section{Material and methods}

\subsection{Molluscs}

Zebra mussels (Dreissena polymorpha P.) were collected at an average depth of $5 \mathrm{~m}$ from Lake Zurich. They were kept in a flow-through tank with dechlorinated tap water for a few weeks up to several months. The water temperature ranged between $12^{\circ}$ and $18^{\circ} \mathrm{C}$. Dreissena were fed twice a week with commercially available dried Spirulina platensis and laboratory-grown fresh Chlorella pyrenoidosa cultures (Nichols, 1992).

\subsection{Microsomal preparations}

All preparatory steps were performed at 0 to $4^{\circ} \mathrm{C}$. Fresh mussels were shucked and the excess water was drained off before the tissue was weighed. Whole mussel tissue and rat liver were homogenised in $0.1 \mathrm{M}$ phosphate buffer $\left(\mathrm{pH} 7.4,3 \mathrm{ml} \mathrm{g}^{-1}\right.$ tissue) with a power driven teflon homogeniser. Homogenates were centrifuged at $10000 \times g$ for $10 \mathrm{~min}$. The resulting mitochondrial pellet was discarded, and the supernatant was centrifuged at $105000 \times g$ for $60 \mathrm{~min}$. The supernatant was then discarded and the microsomal pellet was resuspended in $0.25 \mathrm{M}$ sucrose. Aliquots of resuspended microsomes were stored at $-80^{\circ} \mathrm{C}$ for later determination of protein and cytochrome P450 content, ECOD activity and organophosphate biotransformation capability.

\subsection{Protein assay}

The protein content of the microsomal fractions was determined by the method of Bradford (1976), using bovine serum albumin as standard. Measurements were carried out automatically on a Cobas Fara chemistry analyser (Roche, Switzerland).

\subsection{Determination of cytochrome P450 content}

While determining the cytochrome P450 content of non-purified mussel microsomes (running the baseline of dithionite reduced sample and reference and meas- 
uring cytochrome content of sample bubbled thereafter) with the classical method of Omura and Sato (1964), the presence of a large ' $P 420$ ' peak makes the quantification of the P450 peak difficult and the P450 peak takes at least $20 \mathrm{~min}$ to develop (Livingstone et al., 1989). The cytochrome P450 contents in this study were therefore measured by the carbon monoxide difference spectra of dithionitereduced samples as described by Livingstone (1988). For this, microsomal proteins were diluted with $0.1 \mathrm{M}$ sodium phosphate buffer $(\mathrm{pH} 7.4)$ to a final concentration of $1-1.5 \mathrm{mg}$ per $2 \mathrm{ml}$. The microsomal mixture was divided into two $1-\mathrm{ml}$ cuvettes (1-cm light path). Carbon monoxide was first bubbled for $20 \mathrm{~s}$ into the sample cuvette at a rate of about 2 bubbles $\mathrm{s}^{-1}$. Then, a baseline was recorded from 500 to $400 \mathrm{~nm}$ with a Perkin Elmer 554 spectrometer. Finally, a few grains of sodium dithionite were added to the sample and reference cuvette and mixed thoroughly. The spectra (500 to $400 \mathrm{~nm}$ ) were run several times within 10 min until maximum peak sizes were observed. Cytochrome P450 was quantified from the difference absorbance (A) spectrum of the reference and the samples using the molar extinction coefficient of $0.091 \mathrm{M}^{-1} \mathrm{~cm}^{-1}$ (450 to $490 \mathrm{~nm}$ ) as follows

$\left[\left(\mathrm{A}_{450-490}\right)_{\text {observed }}-\left(\mathrm{A}_{450-490}\right)_{\text {baseline }}\right] / 0.091=\mathrm{nmol} \mathrm{P} 450 \mathrm{ml}^{-1}$

\subsection{ECOD assay}

ECOD (7-ethoxycoumarin O-deethylase) activity was measured as described by Ullrich and Weber (1972). Briefly, approximately $0.5 \mathrm{mg}$ microsomal protein were

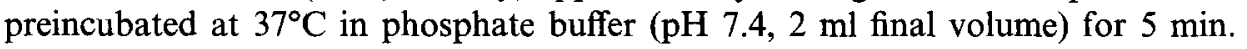

The reaction was started by adding NADPH (Fluka, $0.5 \mathrm{mM}$ final concentration) and ethoxycoumarin (Fluka, in methanol, $0.2 \mathrm{mM}$ final concentration) and allowed to run for $10 \mathrm{~min}$. It was stopped by adding $0.01 \mathrm{~N} \mathrm{HCI}$ (in methanol, $0^{\circ} \mathrm{C}, 1: 1$ reaction mixture volume). After a 1:10 dilution in $0.01 \mathrm{~N} \mathrm{NaOH}$, the amount of hydroxycoumarin was measured with a Perkin Elmer LS50 fluorescence spectrophotometer (excitation $366 \mathrm{~nm}$, emission $466 \mathrm{~nm}$ ). The fluorescence of a series of hydroxycoumarin standards dissolved in $\mathrm{NaOH}(0.01 \mathrm{~N}$ final concentration) was measured. The amount of hydroxycoumarin produced by the microsomes was calculated using a standard curve.

\subsection{Additional ECOD assays with mussel microsomes}

To lower the detection limit of the enzyme (ECOD) activity from $50 \mathrm{pmol} \mathrm{min}^{-1}$ $\mathrm{mg}^{-1}$ protein to $1 \mathrm{pmol} \mathrm{min}{ }^{-1} \mathrm{mg}^{-1}$ protein, dilution of microsomal mussel protein was minimised (incubation of microsomal proteins in only $0.5 \mathrm{ml}$ instead of $2 \mathrm{ml}$ phosphate buffer) and the reaction was allowed to run longer (40 instead of 10 $\min$ ).

Mussel FCOD activity was measured without addition of NADPH as well, as an inhibitory effect of NADPH on mussel ECOD activity was discussed earlier (Kirchin et al., 1992). Further, ECOD activity at $10^{\circ} \mathrm{C}$ (instead of $37^{\circ} \mathrm{C}$ ) was assessed as 
well, in order to determine the metabolising capability closer to the ambient environmental temperature of Dreissena.

\subsection{Organophosphate biotransformation assay}

Whole mussel microsomes and rat liver microsomal preparations ( $2 \mathrm{mg}$ protein $\mathrm{ml}^{-1}$ ) were added to $0.1 \mathrm{M}$ Tris buffer ( $\mathrm{pH} 7.8$ ). The mixture, with a final volume of $2 \mathrm{ml}$, contained $1 \mu \mathrm{g}$ of thiometon and $1 \mu \mathrm{g}$ of disulfoton. The reaction was started by adding $0.25 \mathrm{mM}$ NADPH and was incubated at $22^{\circ} \mathrm{C}$ for 60 min with gentle stirring. The organophosphates thiometon (53.1\%) and disulfoton $(92.3 \%)$ were a gift from Sandoz Agro, Basel, Switzerland.

The whole incubation mixtures $(2 \mathrm{ml})$ were extracted three times with $10 \mathrm{ml}$ of petroleum benzene (Merck). Petroleum benzene extracts were evaporated in vacuo until dry. The residue was then dissolved in $0.1 \mathrm{ml} n$-hexane.

Control incubations were run without the addition of microsomes. The biotransformation in these incubations was $0 \%$. The thiometon and disulfoton contents extracted from the control incubations were taken as $100 \%$ value. Recovery was here $50 \%$, i.e. $0.5 \mu \mathrm{g}$.

\subsection{Additional biotransformation assay}

The time course of organophosphate biotransformation was tested by analysing extracts of rat microsomal incubations after $0,5,15$ and 30 min (Table 1).

Species differences in biotransformation capacity were taken into account by varying the reaction conditions (amount of microsomes, temperature, NADPH) referring to the findings of the previous ECOD experiments (Table 2).

\subsection{Gas chromatography}

The analysis of the parent thiometon and disulfoton contents was carried out with a Carlo Erba HRGC gas chromatograph (GC) equipped with a split/splitless injector and a nitrogen phosphorus detector (NPD). Separation was performed on a glass capillary column coated with $0.15 \mu \mathrm{m}$ OV-31-OH (polysiloxane containing $83 \%$ methyl and 17\% 3-cyanopropyl). The carrier gas was hydrogen at a pressure of $40 \mathrm{kPa}$. The temperature of the injector and detector was $280^{\circ} \mathrm{C}$. One $\mu 1$ of the sample dissolved in $n$-hexane was injected at a split ratio of $1: 10$. The temperature was programmed to increase from $150^{\circ} \mathrm{C}$ (hold time $2 \mathrm{~min}$ ) up to $240^{\circ} \mathrm{C}$ at a rate of $10^{\circ} \mathrm{C} \mathrm{min}^{-1}$. For identification reference compounds dissolved in $n$-hexane were employed. The NPD signals were recorded and integrated with a chromatographic signal processing software (Fisons Chrom-Card No. 5145, Version 1.29). The detection limit was $0.5 \mathrm{ng}$.

\subsection{Mctabolites}

In order to answer the question whether organophosphates were metabolised, 
incubation extracts were analysed by GC/MS for metabolites. The analysis was carried out with a Finnigan MAT 95 mass spectrometer. Separation was performed on a PS086 (polysiloxane containing $86 \%$ methyl and $17 \%$ phenyl) coated glass capillary column using on column injection. The temperature was programmed to increase from $60^{\circ} \mathrm{C}$ (hold time $1 \mathrm{~min}$ ) up to $280^{\circ} \mathrm{C}$ at a rate of $10^{\circ} \mathrm{C} \mathrm{min}{ }^{-1}$.

In order to monitor the parent compounds and their possible metabolites (Fig. 1), the exact masses of the following characteristic molecules and fragment ions were recorded at a mass spectrometric resolution of 10000 :

$\mathrm{m} / \mathrm{e} 184.9860\left(\mathrm{C}_{4} \mathrm{H}_{10} \mathrm{O}_{2} \mathrm{PS}_{2}\right)$ :

(a)

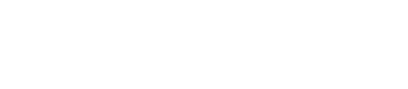

$\mathrm{m} / \mathrm{e}$ 213:0173 $\left(\mathrm{C}_{6} \mathrm{H}_{14} \mathrm{O}_{2} \mathrm{PS}_{2}\right)$ :

$\mathrm{m} / \mathrm{e} 230: 0200\left(\mathrm{C}_{6} \mathrm{H}_{15} \mathrm{O}_{3} \mathrm{PS}_{2}\right)$ :

$\mathrm{m} / \mathrm{e} 258.0513\left(\mathrm{C}_{8} \mathrm{H}_{19} \mathrm{O}_{3} \mathrm{PS}_{2}\right)$ : (i) 0,O-diethyldithiophosphate ion, characteristic for disulfoton and the related sulfone

(ii) isomeric fragment of thiometon formed by loss of the ethylthio moiety, characteristic for thiometon and its related sulfone

fragment of disulfoton formed by loss of the ethylthio moiety, characteristic for disulfoton and its sulfone

molecular ion of demeton- $S$-methyl (oxygen analogue of thiometon)

molecular ion of demeton- $S$ (oxygen analogue of disulfoton)

The ion chromatograms were compared with those of the metabolites expected. The reference compounds demeton- $S$-methyl (the oxygen analogue of thiometon,

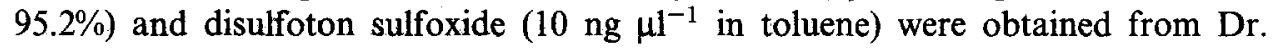
Ehrenstorfer GmbH, Augsburg, FRG. Sulfone analogues of thiometon and disulfoton were obtained by oxidation with potassium permanganate as described in Wisson et al. (1976).

Metabolism was semiquantified by calculating the ratios $\mathrm{T}_{\text {oxy }} / \mathrm{T}, \mathrm{T}_{\text {sulf }} / \mathrm{T}, \mathrm{D}_{\text {oxy }} / \mathrm{D}$, $\mathrm{D}_{\text {sulf }} / \mathrm{D}$ (T, thiometon; $\mathrm{D}$, disulfoton; oxy, oxygen analogues; sulf, sulfones) of the signal areas. Detection limit was set at a signal-background noise ratio of 2 .

\section{Results}

\subsection{Cytochrome P450 content}

The mussel cytochrome P450 contents of two microsomal fractions prepared at an interval of several months were measured. The average content of the whole mussel microsomes of Dreissena polymorpha was $8.4 \mathrm{pmol} \mathrm{mg}^{-1}$ protein derived from $11.7 \pm 2$ pmol $\mathrm{mg}^{-1}$ protein $(n=4)$ of the first and 5.1 pmol $(n=2)$ of the second batch. The cytochrome P450 content in the rat liver was $1270 \pm 127$ pmol $\mathrm{mg}^{-1}$ protein (Table 1). 
Table 1

The microsomal cytochrome P450 content, ECOD activity and organophosphate (OP) biotransformation capacity of Dreissena polymorpha (whole mussel tissue) and rat (liver)

\begin{tabular}{|c|c|c|}
\hline & Whole mussel & Rat liver \\
\hline P450 content (pmol mg ${ }^{-1}$ protein) & 8 & 1270 \\
\hline \multicolumn{3}{|c|}{ ECOD activity (pmol $\min ^{-1} \mathrm{mg}^{-1}$ protein) } \\
\hline $37^{\circ} \mathrm{C}$, with NADPH & n.d. & 91 \\
\hline $37^{\circ} \mathrm{C}$, no NADPH & n.d. & 46 \\
\hline $10^{\circ} \mathrm{C}$, with NADPH & 3 & 60 \\
\hline $10^{\circ} \mathrm{C}$, no $\mathrm{NADPH}$ & 22 & n.d. \\
\hline \multicolumn{3}{|l|}{ OP metabolised (ng pmol ${ }^{-1} \mathrm{P}_{4} 50 \mathrm{~h}^{-1}$ ) } \\
\hline $37^{\circ} \mathrm{C}$, with NADPH & 1 & $>20$ \\
\hline $10^{\circ} \mathrm{C}$, with NADPH & 10 & - \\
\hline $10^{\circ} \mathrm{C}$, no NADPH & 2 & - \\
\hline
\end{tabular}

n.d., not detectable.

\subsection{ECOD activity}

No ECOD activity could be observed in the mussel microsomes when measured at $37^{\circ} \mathrm{C}$ and with addition of NADPH (method of Ullich and Weber, 1972). ECOD activity was detectable, however, when the reaction temperature was kept at $10^{\circ} \mathrm{C}\left(2.8 \pm 0.7 \mathrm{pmol} \mathrm{min}^{-1} \mathrm{mg}^{-1}\right.$ protein, $\left.n=3\right)$. ECOD activity was highest without addition of NADPH $\left(22.3 \pm 13.3 \mathrm{pmol} \mathrm{min}^{-1} \mathrm{mg}^{-1}\right.$ protein, $n=3$, Table 2). ECOD activity of rat liver microsomes were, as expected, highest at $37^{\circ} \mathrm{C}$ in the

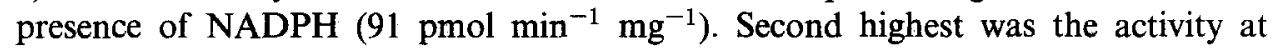
$10^{\circ} \mathrm{C}$ with NADPH $\left(60 \mathrm{pmol} \mathrm{min}^{-1} \mathrm{mg}^{-1}\right)$, then at $37^{\circ} \mathrm{C}$ without NADPH (46 pmol $\mathrm{min}^{-1} \mathrm{mg}^{-1}$ ). At $10^{\circ} \mathrm{C}$ without $\mathrm{NADPH}$, no ECOD activity was detectable (Table $1)$.

\subsection{Biotransformation of organophosphates}

After $1 \mathrm{~h}$ incubation at room temperature $\left(22^{\circ} \mathrm{C}\right)$, almost all added thiometon and disulfoton was metabolised by rat liver microsomes $\left(0.7 \mathrm{mg}\right.$ protein $\mathrm{ml}^{-1}$ incubation mixture). Rat liver microsomes metabolised both thiometon and disulfoton already within a few minutes (Table 2). This occurred when much less microsomal protein was used as well $\left(10 \mu \mathrm{g}\right.$ instead of $0.7 \mathrm{mg}$ protein ml $\mathrm{ml}^{-1}$, data used for calculation in Table 1). At $22^{\circ} \mathrm{C}$ no significant decrease in parent compound concentration could be detected when thiometon and disulfoton were incubated with microsomes $\left(1.85 \mathrm{mg}\right.$ protein $\mathrm{ml}^{-1}$ ) of Dreissena polymorpha. At $10^{\circ} \mathrm{C}$, however, mussel microsome incubations $\left(2.5 \mathrm{mg}\right.$ protein $\mathrm{ml}^{-1}$ ) showed significant differences in recovered organophosphates between control and mussel microsome incubation. In order to compare the capacity for metabolism of rat and mussel microsomes with the assay used in our study, the amount of organophosphate metabolised by $1 \mathrm{pmol}$ of the respective cytochrome P450 was calculated and listed in Table 1. 
Table 2

Metabolism of thiometon $(\mathrm{T}, 1 \mu \mathrm{g})$ and disulfoton $(\mathrm{D}, 1 \mu \mathrm{g})$ by mussel $\left(2 \mathrm{mg}\right.$ protein $\left.\mathrm{ml}^{-1}\right)$ and rat liver microsomes $\left(0.7 \mathrm{mg}\right.$ protein $\left.\mathrm{ml}^{-1}\right)$. Appearance of the sulfones $\left(\mathrm{T}_{\text {sulf }}, \mathrm{D}_{\text {sulf }}\right)$, the oxygen analogues demeton-S-methyl $\left(T_{o x y}\right)$ and demeton- $S\left(\mathrm{D}_{\text {oxy }}\right)$ relative to the parent compounds $(T, D)$

\begin{tabular}{lccccc}
\hline & Incubation time (min) & $\mathrm{T}_{\text {sulf }}$ & $\mathrm{D}_{\text {sulf }}$ & $\mathrm{T}_{\text {oxy }}$ & $\mathrm{D}_{\text {oxy }}$ \\
\hline $\begin{array}{l}\text { Rat - room temperature } \\
\left(22^{\circ} \mathrm{C}\right)\end{array}$ & 0 & n.d. & n.d. & n.d. & n.d. \\
& 5 & 1.2 & 1.7 & 0.4 & 1.3 \\
& 15 & 4.4 & 2.3 & 0.6 & 0.7 \\
Mussel $10^{\circ} \mathrm{C}$ & 30 & $>26$ & $>13$ & n.d. & n.d. \\
With NADPH & 0 & & & & \\
No NADPH & 60 & n.d. & n.d. & n.d. & n.d. \\
& 0 & 0.5 & 0.4 & n.d. & n.d. \\
& 60 & n.d. & n.d. & n.d. & n.d. \\
\hline
\end{tabular}

n.d., not detectable.

\subsection{Metabolites}

Metabolites (oxygen analogues, sulfoxides and sulfones) could be detected in the extracts of the incubation mixture of the rat liver microsomes extract with MS analysis, but not with NPD analysis. In Table 2, the time course of appearance and disappearance of thiometon and disulfoton and their respective metabolites is shown. Metabolites could be found in extracts of mussel microsomes as well, although in considerably lower concentrations than in rat extracts.

\section{Discussion}

This study demonstrated that the freshwater mollusc Dreissena polymorpha is able to biotransform organophosphates in vitro. The lower metabolising of Dreissena in comparison with rat can be sufficiently explained by the lower cytochrome P450 tissue concentration (Table 2). The measurable ECOD activity is an indication for a cytochrome P450 containing oxygenase system. ECOD activity as well as the biotransformation capacity was surprisingly much higher at $10^{\circ} \mathrm{C}$ than at $37^{\circ} \mathrm{C}$ or at $22^{\circ} \mathrm{C}$, respectively.

The low cytochrome P450 content found in Dreissena agrees with cytochrome P450 contents measured in other marine bivalve species. Contents between 3 and $134 \mathrm{pmol} \mathrm{mg}^{-1}$ protein were found in the digestive gland of different marine bivalve species (Livingstone et al., 1989). As the digestive gland of molluscs contains the highest cytochrome P450 content compared with other organs where this enzyme is present in low or non-detectable concentrations, cytochrome P450 of the digestive gland is usually measured (I ivingstone et a1, 1989). In Dreissena, however, the intestinal tissue is intermingled with other parts of the viscera (mostly gonadal tissue) and it is not possible to dissect them separately. Therefore, whole mussel 
tissue of Dreissena was taken for measurement of the P450 content in this study. As a consequence, a lower cytochrome $\mathrm{P} 450$ content per milligram protein was expected, accounting for the 'dilution effect' of the organs with low P450 content. Nevertheless, the measured P450 was within the range of that found in the digestive gland of other bivalve molluscs (Livingstone et al., 1989), and only slightly below that measured in the digestive gland of Mytilus edulis $\left(30-60 \mathrm{pmol} \mathrm{mg}{ }^{-1}\right.$ protein, Kirchin et al., 1992). The difference between the cytochrome P450 contents of the two batches prepared in our study (see Section 3) may be explained by the fact that cytochrome P450 contents in molluscs are subjected to seasonal variation (Solé et al., 1995).

The ECOD activity, developed for the detection of enzyme activities in homeotherm vertebrates, is usually measured at $37^{\circ} \mathrm{C}$. Kirchin et al. (1992) were able to find ECOD activity at $37^{\circ} \mathrm{C}$ in partially purified cytochrome $\mathrm{P} 450$ from the digestive gland of the marine bivalve Mytilus. Maximal ECOD activity of $3 \mathrm{pmol} \mathrm{min}^{-1}$ $\mathrm{mg}^{-1}$ protein was observed in early winter while not detectable in summer.

In our study, the microsomes of whole mussel tissue of Dreissena showed no ECOD activity at $37^{\circ} \mathrm{C}$. At $10^{\circ} \mathrm{C}$, however, activities of up to $30 \mathrm{pmol} \mathrm{min}-1$ $\mathrm{mg}^{-1}$ were measured. Considering that the $\mathrm{P} 450$ contents measured in Mytilus and in Dreissena are around 100 times lower than those in rat (Table 2), the activities of the $\mathrm{P} 450$ monooxygenase system related to the P450 content seems to be similar in molluscs and in vertebrates, when measured at species specific temperatures.

The inhibitory effect (I) of NADPH on ECOD activity observed in Mytilus at concentrations (C) two orders of magnitude below ( $\mathrm{IC}_{50} 2-14 \mu \mathrm{M}$, Kirchin et al., 1992) the one usually used with the method of Ullrich and Weber (1972) could be observed on ECOD activity of Dreissena as well (Table 2).

In spite of being NADPH-independent, many indications suggest that the ECOD reaction in molluscs is nevertheless cytochrome P450-mediated. Some hypotheses explaining the NADPH-independence are discussed by Livingstone et al. (1989). It may reside in an endogenous source of reducing equivalents or in activated oxygen provided as an endogenous peroxide. The latter is possible as almost all the monooxygenase reactions of cytochrome P450 can be carried out by the peroxidase component of its catalytic activity. Furthermore, the inhibitory effect of reducing agents such as NADPH is possibly indicative of a prominent role of a one-electron oxidation. This one electron oxidation would be inhibited by reducing agents such as NADPH. It may therefore be hypothesised that, contrarily to the two-electron monooxygenation in vertebrates, the cytochrome P450 of molluscs catalyses a oneelectron oxidation.

Partially due to this non-requirement and inhibitory effect of reducing agents on the ECOD catalysed reaction, molluscan cytochrome P450 may differ from the cytochrome P450 1A family found in vertebrates (Livingstone et al., 1989). Teunissen et al. (1992) proposed a separate P450 family (CYP10) for molluscs, after having shown that the cytochrome P450 protein of the snail Lymnaea shared less than $40 \%$ positional identity with any known member of the cytochrome $\mathrm{P} 450$ superfamily. The particular cytochrome $\mathrm{P} 450$ isoenzymes of molluses probably 
have similarities to an ancient cytochrome $\mathrm{P} 450$ originating prior to the split leading to the two major coelomate groups of arthropods and chordates (Livingstone et al., 1989).

The results of this study show that mussel microsomes of Dreissena are able to metabolise organophosphates. The very low metabolic activity per milligram protein found in mussel microsomes compared with rat liver microsomes (Table 2) becomes less striking when considering the same aspects as discussed for the ECOD assay. A two orders of magnitude lower rate of metabolism is to be expected due to lower cytochrome P450 content, and the species-specific enzymes reaction temperature has to be adapted. Mussel microsomes metabolised thiometon and disulfoton at a much higher extent at $10^{\circ} \mathrm{C}$ than at room temperature (Table 1). Noteworthy is the fact that mussel microsomes are able to metabolise organophosphates also when NADPH is not present, even if at a lower extent. NADPH therefore does not inhibit organophosphate metabolism, as it has been shown for the ECOD assay, but also does not seem to be essential for it.

Rat microsomes were able to biotransform the organophosphate to an appreciable extent at room temperature (Table 2). Almost all applied organophosphates disappeared after a $1 \mathrm{~h}$ incubation with rat liver microsomes, and appearance as well as disappearance of metabolites in relation to incubation time could be shown. Rat liver microsomes are capable of quickly and efficiently oxidising and hydrolysing organophosphates in vitro. The high rate of thiometon and disulfoton metabolism by the rat liver microsomes found in this study is in accordance with the fact that these organophosphates are also readily metabolised in mammals in vivo (Hill, 1988), as shown in human (Yashiki et al., 1990) and rat (Sandoz, 1979).

The observed metabolism in vitro is likely to occur in Dreissena in vivo as well. The earlier reported lack of organophosphate metabolites in tissue of Dreissena after acute exposures (Dauberschmidt et al., 1996) was therefore rather due to the fact that their concentrations were below the detection limit. A low metabolism could explain the low metabolite concentrations and the accumulation of organophosphates observed in the mollusc. This study showed that the low metabolism may be sufficiently explained by the low enzyme concentration.

In vivo, low metabolism in spite of high body burdens could also be explained by the sequestration hypothesis. The storage of a compound in non-target lipid compartments may explain its accumulation in stable tissue compartments, preventing the compound from being metabolised and contributing to the toxic action (Gallo and Lawryk, 1991; Tanacredel and Cardenas, 1991). In Dreissena, a sequestration in lipids of gonadal tissue or the digestive gland is possible, though not necessary for explaining the low metabolism.

A low metabolism of organophosphates in the mollusc, however, does not explain the observed resistance of Dreissena towards these compounds, as direct application of active oxygen analogue was not toxic to Dreissena either (Dauberschmidt et al., 1996). In order to explain this resistance, investigations of the presence and function of the classical target enzyme cholinesterase in Dreissena are needed. 


\section{Acknowledgements}

This study was supported by a grant from the Swiss Federal Institute of Technology of Zurich (Grant No. 0-20-544-91). Thanks are due to Dr. U. Boelsterli for helpful suggestions and critical reading of the manuscript.

\section{References}

Bradford, M.M. (1976) A rapid and sensitive method for the quantitation of microgram quantities of protein utilizing the principle of protein dye binding. Anal. Biochem. 72, 248-254.

Dauberschmidt, C., D.R. Dietrich and C. Schlatter (1996) Toxicity of organophosphorus insecticides in the zebra mussel Dreissena polymorpha P. Arch. Environ. Contam. Toxicol. 30, 373-378.

De Bruijn, J., W. Seinen and J. Hermens (1993) Biotransformation of organophosphorus compounds by rainbow trout (Oncorhynchus mykiss) liver in relation to bioconcentration. Environ. Toxicol. Chem. 12, $1041-1050$.

Fest, C. and K.J. Schmidt (1970) Insektizide Phosphorsäureester. In: Chemie der Pflanzenschutz- und Schädlingsbekämpfungsmittel, edited by R. Wegler, Springer, Berlin, pp. 246-453.

Gallo, M.A. and N.J. Lawryk (1991) Organic phosphorus pesticides. In: Handbook of Pesticide Toxicology, edited by W.J. Hayes and E.R. Laws, Academic, San Diego, pp. 917-1090.

IIill, E.F. (1988) Brain cholinesterase activity of apparently normal wild birds. J. Wildlife Dis. 24, 51-61.

Kirchin, M.A., A. Wiseman and D.R. Livingstone (1992) Seasonal and sex variation in the mixedfunction oxygenase system of the digestive gland microsomes of the common mussel Mytilus edulis L. Comp. Biochem. Physiol. 101C, 81-91.

Lagadic, L., T. Caquet and F. Ramade (1994) The role of biomarkers in environmental assessment (5). Invertebrate populations and communities. Ecotoxicology 3, 193-208.

Lee, R.F. (1981) Mixed function oxygenases (MFO) in marine invertebrates. Mar. Biol. Lett. 2, 81-105.

Livingstone, D.R. (1988) Responses of microsomal NADPH-cytochrome $c$ reductase activity and cytochrome P-450 in digestive glands of Mytilus edulis and Littorina littorea to environmental and experimental exposure to pollutants. Mar. Ecol. Prog. Ser. 46, 37-43

Livingstone, D.R. (1990) Cytochrome P-450 and oxidative metabolism in invertebrates. Biochem. Soc. Trans. 18, 15-19.

Livingstone, D.R., M.A. Kirchin and A. Wiseman (1989) Cytochrome P-450 and oxidative metabolism in molluscs. Xenobiotica 19, 1041-1062.

Mahendru, V.K. and R.A. Agarwal (1983) Phorate and mexacarbate induced changes in enzymes of the snail, Lymnaea acuminata. Arch. Environ. Contam. Toxicol. 12, 77-82.

Nichols, S.J. (1992) Maintenance of the zebra mussel (Dreissena polymorpha) under laboratory conditions. In: Zebra Mussels: Biology, Impacts, and Control, edited by T.F. Nalepa and D. Schloesser, CRC, Boca Raton, FL, pp. 733-747.

Omura, T. and R. Sato (1964) The carbon monoxide-binding pigment of liver microsomes. I. Evidence for its hemoprotein nature. J. Biol. Chem. 239, 2370-2378.

Payne, J.F. (1984) Mixed-function oxygenases in biological monitoring programs: review of potential usage in different phyla of aquatic animals. In: Fcotoxicological Testing for the Marine Fnvironment, edited by G. Personne, E. Jaspers and C. Claus, State Univ. Ghent and Inst. Mar. Scient. Res., Bredene, Belgium, pp. 625-655.

Payne, J.F., L.L. Fancey, A.D. Rahimtula and E.L. Porter (1987) Review and perspective on the use of mixed-function oxygenase enzymes in biological monitoring: Comp. Biochem. Physiol. 86C, 233-245.

Riviere, J.L. (1992) Hepatic microsomal monooxygenase activities in natural populations of the mallard duck Anas platrhynchos, the tufted duck Aythya fuligula and the great crested grebe Podiceps cristatus. Ecotoxicology 1, 117-135. 
Sandoz (1979) Thiometon (O,O-dimethyl S-2-ethyl-thioethyl phosphorodithioate) metabolism in the rat. Technical report, Sandoz LTD, Agrodevelopment, Basle, Switzerland.

Singh, D.K. and R.A. Agarwal (1983) In vivo and in vitro studies on synergism with acetylcholinesterase pesticides in the snail Lymnaea acuminata. Arch. Environ. Contam. Toxicol. 12, 483-487.

Solé, M., C. Porte and J. Albaigés (1994) Mixed-function oxygenase system components and antioxidant enzymes in different marine bivalves: its relation with contaminant body burdens. Aquat. Toxicol. 30, 271-283.

Solé, M., C. Porte and J. Albaigés (1995) Seasonal variation in the mixed-function oxygenase system and antioxidant enzymes of the mussel (Mytilus galloprovinciallis). Environ. Toxicol. Chem. 14, 157-164.

Suteau, P.M., M.L. Migaud and J.F. Narbonne (1987) $\Lambda$ bsorption and tissue distribution of radioactivity in mussels (Mytilus galloprovincialis) exposed to low concentrations of ${ }^{14} \mathrm{C}$-polychlorinated biphenyl. Sci. Tot. Environ. 67, 187-193.

Takimoto, Y., M. Oshima and J. Miyamoto (1987) Comparative metabolism of fenitrothion in aquatic organisms. II. Metabolism in the freshwater snails, Cipangopaludins japonica and Physa acuta. Ecotoxicol. Environ. Safety 13, 118-125.

Tanacredel, J.T. and R.R. Cardenas (1991) Biodepuration of polynuclear aromatic hydrocarbons from a bivalve mollusc, Mercenaria mercenaria L. Environ. Sci. Technol. 25, 1453-1461.

Teunissen, Y., W.P. Geraerts, H. van Heerikhuizen, R.J. Planta and J. Joosse (1992) Molecular cloning of a cDNA encoding a member of a novel cytochrome P450 family in the mollusc Lymnea staginalis. J. Biochem. Tokyo 112, 249-252.

Ullrich, V. and P. Weber (1972) The O-dealkylation of 7-ethoxycoumarin by liver microsomes. A direct fluorometric test. Hoppe-Seyler's Z. Physiol. Chem. 353, 1171-1177.

Wisson, M., C. Van Hoek and H.H. Sauer (1976) Thiometon. In: G. Zweig (Editor), Analytical Methods for Pesticides and Plant Growth Regulators, Vol. VIII. Academic, NY, pp. 239-248.

Yashiki, M., T. Kojima, M. Ohtani, F. Chikasue and T. Miyazaki (1990) Determination of disulfoton and its metabolites in the body fluids of a disyston $\circledast$ intoxication case. Forensic Sci. Int. 48, 145-154. 